\title{
Legal Sector Reform Pursuits in Ethiopia: Gaps in Grassroots Empowerment
}

Abstract

Elias N. Stebek *

The initial phase of Ethiopia's Justice System Reform Program (which includes legal sector reform and judicial reform) was very ambitious with exemplary levels of zeal, budgetary allocation and commitment. This seems to have been followed by the fragmentation of reform efforts in the midst of inadequate grassroots empowerment (in decision making and resource management) while at the same time the legal sector espoused comparably similar aspirations. There is thus the need for distinct institution-level reform tasks and empowerment in legislative drafting, law enforcement, legal education (including research and training) and access to justice. The reinvigoration of legal sector reform in Ethiopia envisages merit-based recruitment and promotion accompanied by grassroots empowerment in decision making and resource management in the context of adequate harmonization among organs and institutions of the sector. It also envisages broad-based participation including enhanced involvement of civil society organizations. This article briefly examines the level of attention given to and the gaps in reform pursuits in lawmaking, law enforcement, legal education and access to justice.

\section{Key terms}

Lawmaking, law enforcement, legal education, access to justice, legal information, the Bar, legal aid, civil societies, Ethiopia

DOI http://dx.doi.org/10.4314/mlr.v9i2.2

\section{Introduction}

Positive development in each component of the justice system contributes to the overall improvement in the realms of rule of law, good governance and democratization; and meanwhile, the justice system benefits from the positive causal reciprocity of each element or subsystem that determines the strengths or

\footnotetext{
* Elias N. Stebek (LL.B, LL.M, PhD), Associate Professor, St. Mary’s University, School of Graduate Studies. I thank the anonymous reviewers for their comments and feedback.

Most sections of the earlier version of this article were part of an unpublished research paper titled "Assessment of Ethiopia's Justice Sector Reform Components in GTP I and Draft GTP II" (preliminary version: dated 30 November 2015) which was submitted to Ethiopian Lawyers Association (ELA). I thank ELA for the opportunity, and I also thank the Civil Society Fund II Programme of the European Union (EU CSF II) for financing the research including the Panel Discussion conducted on December 11, 2015.
} 
shortcomings of the aggregate. In other words, success or failure in each component positively or negatively contributes to the progress or regression of the justice system. The 2005 Comprehensive Justice System Reform Program ${ }^{1}$ (CJSRP) had thus duly adopted a holistic approach in addressing the gaps and challenges in Ethiopia's justice system.

Ethiopia's Comprehensive Justice System Reform Program (CJSRP) included institutions and processes that come under different organs of the state. On the other hand, the holistic nature of the reform had created synergy and harmony in spite of functional divergence attributable to the legislative, judicial and executive nature of the specific mandates and responsibilities of the various components of the justice system.

It is indeed commendable that the CJSRP opted to pursue a holistic approach in justice system reform rather than fragmented and piecemeal reform pursuits. It is equally important to note that such holistic approach can further include other components of the justice system in addition to the categories stated in the 2005 CJSRP. However, such frontier expansion of justice system components requires safeguards against the risk of diluting or weakening the efficiency and effectiveness of reform at the grassroots.

The four core components and a fifth crosscutting component of comprehensive Justice System Reform Program identified in the 2005 Baseline study involved (a) lawmaking and revision; (b) the judiciary; (c) law enforcement which includes prosecutors, the police and the penitentiary system; (d) legal education and research; and (e) information flow within and outside the justice system. These can be reformulated as five components and one enabler as indicators Ethiopia's justice sector reform: (a) institutions, processes and procedures in lawmaking and revision, (b) the judiciary; (c) law enforcement with particular reference to the police, public prosecutor services, and prisons; (d) legal education, training and legal research; (e) access to justice which include legal information, the Bar, legal aid, alternative dispute resolution, traditional systems that are in conformity with the FDRE Constitution, and the engagement of the legal profession and civil societies in enhancing access to justice; and (f) good governance in the justice sector. The first five components encompass the justice system loop that is interconnected, and they also require the sixth component, i.e., good governance as a cross-cutting enabler.

The component of judicial reform is covered in a separate article published in this issue (pp. 215-257), and this article deals with reform pursuits and challenges in the remaining elements of justice system reform. The following sections respectively highlight the pursuits of reform and challenges in

\footnotetext{
${ }^{1}$ Ministry of Capacity Building, Justice System Reform Program Office (2005), Comprehensive Justice System Reform Program Baseline Study Report, February 2005
} 
lawmaking and revision, law enforcement, legal education, access to justice and good governance. These components indeed deserve separate scholarly articles, toward which this article can provide an introductory discussion so that further research can separately address the components and sub-components in depth.

\section{Lawmaking and Revision}

\subsection{Some Views on Drafting Effective Legislation}

Robert Seidman and Ann Seidman suggest a problem solving methodology in lawmaking. According to the normative methodology advocated by the Seidmans, lawmakers are expected 'to describe and explain the behaviours that block good governance and development, i.e. the behaviours that are targeted in development oriented legislation". ${ }^{2}$ This methodology requires drafters to "be engaged in the process of fact-finding and analysis" so that they "can design proposals and norms likely to induce a positive change of behaviour. After a bill made based on this has been enacted into law, the law's progress should be monitored and evaluated". 3

The Seidmans contrast their problem-solving lawmaking process with two earlier models: the ends-means methodology that defines an end and looks for the most efficient means to achieve such end, and incrementalism, which tries to stay closest to the current situation at hand and recognises the difficulty of large changes. Seidman and Seidman's contribution also explores the question of how law can induce the desired social change necessary for development. ${ }^{4}$

Arnscheidt et al outline a set of seven interrelated causal factors which, according to the Seidmans, facilitate the drafting process. These steps are expressed with the acronym ROCCIPI which represent:

- Rules (prescribing how actors should behave),

- Opportunity (the environmental circumstances which facilitate or thwart the specified problematic behaviour),

- Capacity (the actor's ability to behave as prescribed in the law or contrary to it),

- Communication (whether the actor knows the rules),

- Interest (factors which the actors view as incentives for behaving as they do),

- Process (the procedures by which the actor decides whether or not to obey the rule), and

\footnotetext{
${ }^{2}$ J. Arnscheidt, B. van Rooij \& J.M. Otto (editors), 2008. Lawmaking for Development, Leiden University Press, p. 15.

${ }^{3}$ Ibid.

${ }^{4}$ Ibid.
} 
- Ideology (the actors' own values beliefs, attitudes that influence their behaviour). ${ }^{5}$

Seidman and Seidman note that the quality of rules depends on "the extent to which the law is able to affect these factors". This methodology "was used in Zambia to do research preparation for a new law proposing to establish a Commission on Law and Integrated National Development". It aspired to "end arbitrary lawmaking of the past". This methodology, according to the Seidmans can come up with well-made and well-founded research report which "ought to persuade the 'rational sceptical reader' and lead to the adoption of the actual law and enhance the chances of its implementation". 6

However, Van der Vlies raises the question at to "how responsive legislation - laws that respond to values, interests, needs, and demands in society- can be made given the fragmentation of such societies" particularly where a legislation operates at a global scale. ${ }^{7}$ In relation to such legislation, she suggests "exchange of knowledge by legislators in different countries, comparison of rules in different countries, legislative transplantation, and the preparation of treaties". 8

Based on his experience in GTZ projects, Deppe discusses the legal reform in Central Asia which at first "meant making new laws, often even the direct copying of laws, from Western countries".

By doing so, Western donors wanted to strengthen Central Asia's commercial ties with the West, focusing on the reform of civil and trade laws. Success was measured by the number of laws passed or by polling the opinions of the business community. However, the results of such legislative reform were disappointing. As Deppe argues, this was largely due to the fact that the original reforms lacked realism, patience, and local suitability. In addition, there was too little attention paid to implementation, which the author holds does not come automatically. He concludes that successful legal reform first of all needs time, which many of the current projects with their two to five year time span do not have. Second, reforms need to be holistic, combining legislative assistance with legal training, dissemination, public information, institution building, harmonisation, and monitoring. ${ }^{9}$

\footnotetext{
${ }^{5}$ Id., p. 16.

${ }^{6}$ Ibid.

${ }^{7}$ Id. p. $16,17$.

${ }^{8}$ Id. p. 17.

${ }^{9}$ Ibid.
} 


\subsection{Overview of Ethiopia's legislative drafting reform pursuits}

The aspirations of Ethiopia's Justice System Reform Program transcend the technical skills of drafting and amending laws. To this end, a manual ${ }^{10}$ was prepared which, inter alia, underlines the need for research as the foundation of legislative drafting. As Section 3.1 of the draft indicates, "[a] drafter is the craftsperson" who writes down "public policies and ideas into a textually rigid form that can be given legal effect" and "whose task is to help resolve a problem by legislative means". ${ }^{11}$ The Manual underlines that legislative "drafting shall be preceded by a thorough appraisal of the real problem and proper understanding of the nature of policies to be implemented, which can be properly attained through research". ${ }^{12}$ In short, "research is an integral part of legislative drafting". ${ }^{13}$

According to the Manual, drafters should address the following in their research in connection with policies:

a) Determine the nature and scope of the policy sought to be implemented;

b) Identify, if there are any, other policies that have direct or indirect relationship with the policy sought to be implemented;

c) Determine the possible options for giving effect to the policy;

d) Decide whether the policy [can] be realized through legislation rather than by non-legislative means;

e) Identify whether the policy must be dealt with by primary legislation (proclamation) or secondary legislation (for example, regulation);

Effective legislation is the realistic textual articulation of policies and values toward solving problems based on research. It can also serve as proactive means of averting problems prior to their occurrence. Research that serves as the basis for effective legislation is forward looking and it facilitates upcoming progress and development. The Manual notes that research should pay attention to the following prior to drafting:

a) "Define the problem(s) correctly in terms of: [i] Nature, [ii] Scope, [iii] Frequency, [iv] Consequence (effect) ... etc;

b) Determine whether government action is justified to deal with the problem; because, sometimes, a problem may be effectively handled and resolved by, for example, non-governmental actors;

c) If government action is justified, identify the options for dealing with the problems, i.e. [whether] legislative or non legislative options [are appropriate];

\footnotetext{
${ }^{10}$ Legislative Drafting Manual, Justice System Reform Program, December 2007.

${ }^{11}$ Id., Section 3.1.3

${ }^{12}$ Ibid.

13 Ibid.
} 
d) Study the likely benefits from each option in terms of: [i] Effectiveness, [ii] Cost, [iii] Gains, etc;

e) If legislation is the preferable form of government action, make sure that the matter cannot be dealt with under existing law;

f) Identify whether the appropriate legislation is proclamation or regulation."

Justice and Legal System Research Institute (JLSRI) had organized a workshop on legislative drafting in 2008. Based on the initiative of Adamseged Belay $^{14}$, an invitation (for trainers) was sent to renowned professors in the field of legislative drafting. The following paragraph of the letter sent to professors at Boston University, indicates the purpose of the training:

The purpose of the workshop is capacity building in legislative drafting expertise with the objective of institutionalizing a learning process for equipping participants with legislative theory, methodology and methods of drafting effective legislation in tune with Ethiopia's development. Participants of the workshop will be lawyers from various institutions whose jobs are related to drafting and instructors from law schools who teach legislative drafting. ${ }^{15}$

Based on this invitation, the Training on Legislative Drafting was conducted in 2008. As the introductory outline of the Training on Legislative Drafting developed by Robert Seidman, Ann Seidman and Lorna Seitz indicates, the detailed provisions of a bill (draft law) constitute a design for legislative solution "grounded on facts [that are] logically organized" and which are "likely to overcome the causes" of the problems. ${ }^{16}$ To this end, pre-drafting tasks include (a) "identifying alternative possible solutions, (b) showing "preferred solutions' that are logical and that overcome causes of problematic behaviours"; and (c) showing that "estimated social and economic benefits" of the law to be legislated "outweigh probable social and economic costs". ${ }^{17}$

The capacity enhancement aspirations of the justice sector reform in lawmaking and revision had targeted at enhancing professionalism in drafting

\footnotetext{
${ }^{14}$ Director General, Justice and Legal System Research Institute (2006-2010).

${ }^{15}$ Letter from Ato Adamseged Belay, Director General of JLSRI, to Professor Anne Seidman and Lorna Seitz dated, February 28, 2008, Ref. No. 02/13/35-2/1, paragraph 2.

16 The training was conducted by Professor Ann Seidman and Lorna Seitz, Boston University, in May 2008. The training was a take-off point in capacity building in the realm of legislative drafting. Although the legislative drafting is usually perceived in a simplistic context of drafting laws based on policy decisions, effective lawmaking involves deeper issues and considerations. See for example, Ann Seidman and Robert B. Seidman (2009), "ILTAM: Drafting Evidence-Based Legislation for Democratic Social Change", Boston University Law Review, Vol. 89, pp. 435-485.

${ }^{17}$ Introductory outline of the Training on Legislative Drafting, Ibid.
} 
laws with particular attention to organs that have active involvement in drafting and enacting laws. In the absence of sustained reform and capacity building in legislative drafting, laws can continue to be spontaneous, fragmented, inconsistent and largely uncertain. Under such circumstances, new laws or amendments can be counterproductive by bringing about heavier social and economic cost in comparison with the purpose they purport to serve. Examples in this regard include (a) hasty lawmaking which can be counterproductive due to gaps in research and stakeholder engagement, (b) provisions that encourage arbitrary executive behaviour thereby prompting wider rooms for corruption and abuse of power, and (c) ambiguities and fragmentation in the law which can cause miscarriage of justice due to unpredictable judicial and administrative decisions.

\subsection{The lawmaking component in GTP II}

Section 7.1.4 of GTP II (December 2015) embodies Ethiopia's Growth and Transformation Plan for the years 2015/16- 2019/20. It has five paragraphs ${ }^{18}$ which include the main targets of the justice sector during the GTP II period. The elements that specifically refer to lawmaking and revision in paragraphs 1 , 2 and 5 are:

- ensuring that the drafting, revision, enforcement and interpretation of laws are in conformity with the Constitution (paragraph 1),

- adequate legal framework required for development and democratization (paragraph 2),

- The preparation and implementation of Manual for legal drafting (paragraph 5), and

- Ensuring that international agreements are signed and ratified based on their conformity with the Ethiopia's national, foreign and security policies and ensuring their contribution to the political, social and economic interests of the country (paragraph 5).

The fourth paragraph of Section 7.1.4 of GTP II embodies eleven elements that can be identified as targets in the domain of lawmaking and revision during GTP II. These targets are stated after the following introductory statements that can serve as framework for the targets:

"Rule of law is one of the principles of good governance and it requires all political activities to be conducted in accordance with the Constitution and

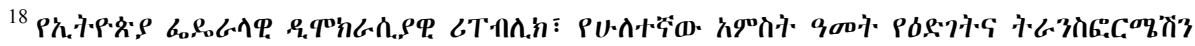

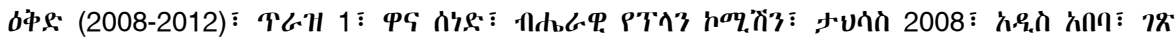
168: 169::

Federal Democratic Republic of Ethiopia, Second Five Year Growth and Transformation Plan (2015/16- 2019/20), Volume 1, Main Text, National Planning Commission, December 2015, Addis Ababa, (Amharic version), pp. 168, 169.
} 
other laws, and it indicates that all are equal before the law and accountable thereof. The achievements in this regard will be enhanced to higher levels. Accordingly, laws will be drafted and implemented based on research to ensure that they are in conformity with the Constitution and current global realities".

The laws that are expected to be drafted (during the GTP II period) and submitted to the relevant organs are:

a) the Criminal Procedure Code;

b) Administrative Law;

c) Private International Law (conflict of laws);

d) Alternative Dispute Resolution draft laws;

e) Draft Proclamation for the Licensing and Administration of Advocates;

f) Proclamation to Protect Witnesses and Informants ( $(\boldsymbol{m} \boldsymbol{q} \boldsymbol{q}, \boldsymbol{g}$ 年) in criminal cases along with regulations and directives; ${ }^{19}$

g) Draft Proclamation to amend the Criminal Code;

h) Draft Regulations on Advocate Licence fee;

i) Amendment regulations for the administration of federal prosecutors;

j) Amendment of the Labour Proclamation in accordance of the Labour Policy and in accordance with Ethiopia's interest in development and investment; and

k) draft amendment on the law of extra contractual liability (torts) based on research to evaluate its current state.

Even if GTP II gives due attention to various law revisions, the most important factor in lawmaking is the level of attention that should be given to research and the adequacy and validity of assessments that should precede lawmaking and revision. "Most of these drafts have been a work in progress over ten years" and "there are even some official reports which had created the assumption that some of the draft revisions have been completed". ${ }^{20}$ Although there is concern about the decline in quality of legal drafting in Ethiopia, the pace of the reform toward addressing the challenge seems to be very slow.

The tasks of legislative drafting in the targets stated above will indeed benefit from the "preparation and implementation of Manual for legal drafting", which is one of the targets for the GTP II period. This target is expected to have a broader conception of legislative drafting which involves the tasks of research and analysis (or problems and options of solution) rather than the mechanical transposition of policy decisions into legal provisions.

\footnotetext{
${ }^{19}$ Moreover, a system shall be formulated regarding the implementation of the services of witnesses and informants.

${ }^{20}$ Comment from one of the external assessors.
} 
The issues (in Section 1.1) raised by the Seidmans, Vlies and Deppe can indeed inform the lawmaking and law revision plans that are stated in Ethiopia's GTP II. The measure of achievement in the eleven categories of laws (stated above) that are planned to be drafted during the GTP II period does not solely lie in their drafting and enactment. The laws will rather be evaluated on the basis of their outcomes and impact. This requires reinvigorating the wider conception of legislative drafting that was espoused during the earlier phases of the justice sector reform program, as highlighted in Section 1.2.

In the absence of such precautions, the problems of fragmentation of laws and their impact on legal uncertainty are bound to increase. As Tariku Wondimagegnehu notes, "laws enacted by various institutions are becoming too fragmented and confusing" and thus "the laws should be streamlined through a single institution". ${ }^{21}$ This calls for research-based and analytic approach to lawmaking and revision. Good practices show that law commissions are entrusted with the tasks of legislative drafting so that laws can be integrated and coherent. In the Ethiopian context, the Ministry of Justice and JLSRI (Justice and Legal System Research Institute, which is currently under the supervision of the Ministry) are expected to play the role of legal expertise and advising in legislative drafting. According to Desalegn Mengistie, "there is a recent decision to harmonize drafting of laws, and all executive offices should submit their drafts to the Ministry of Justice before they are sent to the HoPR as draft laws", and he expects that "this will be practical soon". ${ }^{22}$

Fragmentation does not only bring about ambiguities, over-regulation and uncertainty, but it also causes inefficiency and duplicity of efforts. A case in point was the 2004 Criminal Code which was revised and re-drafted during the early stage Ethiopia's justice system reform pursuits. The "fragmentation of criminal law through the inclusion of penal provisions in the draft proclamations prepared by different institutions was an issue of concern. This problem of fragmentation persists after over a decade of reform efforts. This shows absence of adequate harmonization at various levels". ${ }^{23}$

Harmonization does not only refer to lawmaking, but also relates to the harmony and interdependence between the various reforms in the other components of the justice system. The initial justice sector initiatives in Latin America, for example, focused on law reforms. However, it soon became clear

${ }^{21}$ Ato Tariku Wondimagegnehu, Ministry of Public Service \& Human Resource Development, Panel Discussion (organized by Ethiopian Lawyers Association) on Justice Sector Reform Components in GTP I and Draft GTP II, 11 December 2015, Churchill Hotel.

${ }^{22}$ Ato Desalegn Mengistie, Director, Justice System Reform Program, Ministry of Justice, Panel Discussion, Panel Discussion, Ibid.

${ }^{23}$ Comments from one of the external assessors. 
that in the absence of other changes law reforms have little impact. ${ }^{24}$ There was thus "growing recognition and incorporation of additional elements to turn legal theory into practice". Bedner states that these included:

"training programs, the creation of new organizations (public defense and prosecution), restructuring and reorientation of existing ones (the courts, police, ..., public ministries responsible for prosecution), provision of new equipment and infrastructure more compatible with the new procedural requirements, education of private lawyers and law students, and public information campaigns. ${ }^{25}$

Lawmaking is not thus an end-in-itself, but a component that should be accompanied by appropriate, effective and efficient interpretation and implementation.

\section{Law Enforcement Organs}

\subsection{GTP II Targets in Law Enforcement}

The following targets in the first paragraph ${ }^{26}$ of Section 7.1.4 of GTP II refer to law enforcement:

- Strengthening the effectiveness of justice through enabling the justice system to obtain valid and truthful evidence;

- Ensuring that the drafting, revision, enforcement and interpretation of laws are in conformity with the Constitution;

- Strengthening the capacity of justice system institutions with regard to human resources, knowledge, skills and equipment;

- enhancing the culture and habit of peaceful resolution of conflict.

Among the eight targets under the second paragraph ${ }^{27}$, the following are relevant to the law enforcement component of justice sector reform:

- Ensure rule of law through the implementation and interpretation of laws based on their purpose;

- Bring about institutional reform towards the attainment of [the objectives here-above, i.e., democratization and rule of law] and toward the pursuit of accelerated and sustainable development;

- Tasks that strengthen the processes, organization and human resource toward effective justice system;

${ }^{24}$ Andrian Bedner (2008), Court Reform. Law, Governance and Development, Policy Notes, Leiden University Press, p. 10.

${ }^{25}$ Ibid, footnotes omitted.

${ }^{26}$ GTP II, supra note 18 , p. 168.

27 Ibid. 
- In collaboration with the public, combat the tendencies of corruption and gaps in fair trial, and enable the justice system to win public confidence.

The first target item in the third paragraph ${ }^{28}$ applies to all justice sector institutions. It aims at "capacity building with regard to justice system institutions and their human resource, and building the human resource capacity of justice sector institutions in a planned and institutional approach through training to enhance capacity in attitudes, integrity, knowledge and skills." Among the ten targets that can be identified in the fifth paragraph, ${ }^{29}$ the following directly or generally relate to law enforcement:

- The preparation and implementation of crime prevention strategy;

- Monitor and support the effective implementation of the National Human Rights Action Plan to ensure respect for human rights; and

- Enhance good governance through awareness against corruption and raising awareness about its adverse social and economic impact so that the society does not tolerate corruption.

\subsection{Law Enforcement in Criminal Justice}

The criminal justice process involves (a) interrogation of accused persons by the police (b) investigation by the public prosecutor which institutes charge, and (c) enforcement of committal for trial or enforcement of sentences by prison administrations. As these three organs enforce the law, their success or failure is not measured by the number of convictions or case attritions, but by the level of their professionalism and integrity in the course of fair, competent, responsible, effective and efficient performance in accordance with the law.

A criminal justice system may have a spectrum of features ranging from primacy to due process vis-à-vis focus on crime control. The determinant factors may be the level of peace, shared values, democratization, crime rates, government legitimacy, national consensus, and other variables. Even when criminal justice systems are forced to give primacy to the crime control model rather than the due process model, they are expected to consider potential infringements of due process as transient (that would recede proportionate to the decline of crime rates, civil wars or terrorism). The justice system in such settings is expected to consider its emphasis on crime control (rather than due process) as transient, because it envisages that the due process model ultimately deserves to be in the mainstream.

The distinct functions of the Police and the Public Prosecutor under the Ethiopian Criminal Procedure Code reflect the due process model so that the police and public prosecutor would independently conduct their law

\footnotetext{
${ }^{28}$ Ibid.

${ }^{29}$ Id., p. 169.
} 
enforcement mandates. However, in settings of rising crime rates (as in the case of substantial numbers of petty theft "in locations such as Addis Ketema, regional bus terminal in Addis Ababa"30) the due process model may tend to create case loads on both parties, and the pursuit of efficiency may, at times, give primacy to the 'efficient' means of search for truth through the functional coordination of the police and public prosecution. This is because the dictum 'justice delayed is justice denied' may require the option of embracing the lesser evil. Law enforcement agencies under such settings may thus encounter push factors toward giving primacy to faster means of managing cases.

Real Time Dispatch (RTD) which allows the joint tasks of the Police and Public Prosecutor falls under the crime control model. Yet, justice systems are not expected to consider such schemes as their ultimate aspiration in strategic five-year plans. Targets (iii) and (vii) which were embodied in the earlier April 2015 Draft of GTP II respectively had aimed at:

- 'a system which ensures and evaluates the effectiveness and efficiency of the criminal justice system with particular attention to attrition rates, conviction rates etc.'; and

- 'capacity enhancement in the investigation, prosecution and conviction of persons accused of corruption and confiscation of property obtained by corrupt practices'.

The fourth target under the third paragraph of the April 2015 version of Draft

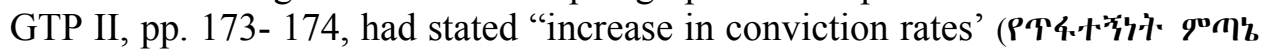

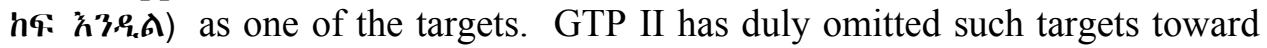
increasing conviction rates. The percentage of convictions among the cases handled by a public prosecutor cannot be an objective threshold of evaluating professional service and effectiveness. The police and the public prosecutor are entrusted with the task of enforcing the law, and not enhancing conviction rates. A case which, for example, results in the release of a suspect from custody due to inadequate evidence does not prove the weakness of the police in charge. The same holds true for acquittal after charge. Criminal investigation or criminal prosecution is not a competitive game, and a verdict of not guilty shall not represent 'underperformance' for the police or the public prosecutor. The ultimate raison d'être of both institutions is law enforcement, including the release of innocent persons.

At a recent workshop, a practicing attorney raised a question: "In view of current efforts to raise the conviction rate in Ethiopia to nearly to $100 \%$, why

${ }^{30}$ This example was raised during interview with Ato Desalegn Mengistie, Justice System Reform Program Director, Ministry of Justice, November 24, 2015. 
should there be discussion about public defender services and legal aid"? ${ }^{31} \mathrm{He}$ meant to imply that the decision is already made by the organ which files the charge if the conviction rate is planned to be close to $100 \%$. The question evoked many reflections and observations. According Ato Tamrat Kidanemariam, "the purpose of a criminal justice system is to punish the offender and to acquit the innocent, and in effect, non-conviction of innocent persons cannot be regarded by the public prosecutor as losing a case". ${ }^{32}$

There can be an argument that such conviction rates may serve as disincentive against filing charges on cases in which the likelihood of conviction is uncertain. However, such disincentives should not come from the evaluation of the performance of public prosecutors based on the rates of convictions in the cases they handle, but from the proper enforcement of the law which protects innocent persons from conviction based on the thresholds embodied under the Criminal Procedure Code or other laws of procedure.

One of the themes of focus in the 2005 Comprehensive Justice System Reform Program is the demilitarization of the police in training and institutional arrangements thereby "treating the police as service rather than a force. The same focus and attention was also given to reforming the penitentiary system". 33 Although "significant achievements were recorded during the first phase of the reform including changing the legal framework, the organizational and functional structure, the training system and abolishing the military ranking of police and prison officers", ${ }^{34}$ sustained attention is expected in this aspect of the reform.

Another concern in the realm of law enforcement that was stated in the 2005 CJSRP Baseline Study was the fragmentation of prosecutorial authority. This challenge is steadily growing as the criminal law regime and public prosecutors in charge are becoming fragmented. As stated in Section 1.3, there is a plan to amend regulations for the administration of federal prosecutors under GTP II. There is also a project to establish General Prosecutor's Office as one of the forty projects for the GTP II period under the Good Governance Cluster Reform. Yet, these statements are too general and they should be interpreted to mean the establishment of the General Public Prosecutor's office which is independent and which resolves the challenges and gaps in the fragmentation of prosecutorial authority.

\footnotetext{
${ }^{31}$ Validation workshop organized by Ethiopian Lawyers Association on "Public Defender's Services in Ethiopia: Assessment of Current Gaps and the Way Forward", Jupiter Hotel, 16 November 2015.

${ }^{32}$ Ibid.

${ }^{33}$ Comment from one of the external assessors.

${ }^{34}$ Ibid
} 
Moreover, combating corruption in law enforcement is among Ethiopia's justice sector reform pursuits. A study presented at the Workshop on Indicators to Combat Corruption in Ethiopia's Justice Sector ${ }^{35}$ has presented findings on the various institutions of the justice sector including the police, public prosecutor offices and prison administrations. The study identifies the types of corruption to which these organs are exposed. The corrupt practices in law enforcement institutions include taking bribes, poor performance ( embezzlement, misuse of authority (ก

The study attributes these acts of corruption particularly to inadequate knowledge and skills, low salary scales and low level of financial benefits, discretionary powers, lack of transparency and service delivery systems. ${ }^{36}$ According to the study, other factors that induce corrupt practices in the police include closer relations with offenders, poor level of recognition given to good performance, and failure to disclose corrupt practices due to the level of friendship which prevails among colleagues in the same unit. ${ }^{37}$ The specific factors that are challenges in prison reform include problems of inadequate prison space, level of awareness in prison handling, and unprofessional relations with prisoners.

\subsection{Civil Justice Reform}

Law enforcement in the civil justice system involves many institutions of the executive. One of the areas of focus in this regard should be the susceptibility of administrative tribunals to arbitrary decisions in interpreting laws and regulations. Cases in point are administrative tribunals that deal with urban land expropriation, eviction and compensation. These tribunals established under the administrative authorities (that are parties in the litigation) are empowered to adjudicate and decide cases in spite of their interest in the outcome of the case.

The extent to which ambiguities and discretionary power are avoided in the demarcation lines between administrative and legislative functions, or between administrative and judicial functions determine the level of check and balance against abuse of authority by administrative entities. ... The advantage of administrative tribunals relates to efficiency and effectiveness in contrast to judicial processes that might cause delay. However, experience in the complaints against expropriation and the amount of compensation

\footnotetext{
${ }^{35}$ Workshop on Indicators to Combat Corruption in Ethiopia's Justice Sector, A research conducted by Justice and Legal System Research Institute, Ghion Hotel, October 20,

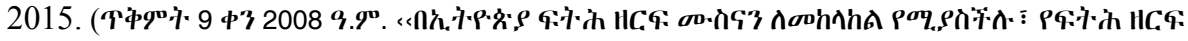

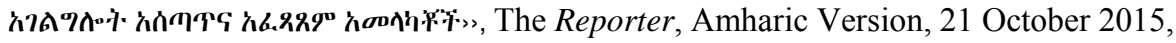
Reported by Tamiru Tsige.

${ }^{36}$ Ibid.

${ }^{37}$ Ibid.
} 
show that equal attention ought to be given to the issue of impartiality through, for example, judicial review and stakeholder representation when members of administrative tribunals are appointed. ${ }^{38}$

As Aron and Abdulatif noted, although "modern states cannot effectively function without allowing the administrative agencies to have such roles" this should be done with "the caveat that the agencies should be kept in check by procedural stipulations and schemes". ${ }^{39}$ They duly underline the "gap in the Ethiopian legal regime due to the absence of administrative procedure law" even though the Draft Federal Administrative Procedure Proclamation (2004) was drafted a decade ago.

Fair adjudication requires safeguards of stakeholder participation in the membership of all administrative tribunals and it envisages judicial review upon exhaustion of all administrative remedies. Likewise, administrative rulemaking procedures should clearly regulate the rulemaking function of administrative agencies. In the absence of these safeguards against arbitrary decisions without judicial scrutiny and unless administrative remaking is harnessed by administrative procedure law, civil justice can hardly be possible. GTP II does not address the gaps in the civil justice system with regard to stakeholder representation in administrative tribunals and judicial review. As indicated in Section 1 above, GTP II states administrative law as one of the laws that will be drafted and submitted to the relevant organs. This law is, inter alia, expected to include administrative rulemaking and delimit the scope of authority of administrative tribunals.

\section{Legal Education, Research and Training}

About two decades ago Dakolias had, in the context of Latin America, stated the following on the role of legal education in justice system reform:

Legal education and training is fundamental for judicial reform. ... The quality of law schools has been deteriorating ... . In most Latin American countries the public universities have no entrance requirements, and each school establishes its own graduation requirements. Due to low salaries, law professors usually work on a part-time basis, and therefore, have little time to devote to research. As a result, judges often are not prepared for the bench. ${ }^{41}$

${ }^{38}$ Elias N. Stebek (2013), "Role conflict between Land Allocation and Municipal Functions in Addis Ababa", Mizan Law Review, Vol. 7, No. 2, p. 263.

${ }^{39}$ Aron Degol \& Abdulatif Kedir (2013), "Administrative Rulemaking in Ethiopia: Normative and Institutional Framework", Mizan Law Review, Vol. 7, No. 1, p. 1.

${ }^{40}$ Ibid.

${ }^{41}$ Maria Dakolias (1996). The Judicial Sector in Latin America and the Caribbean Elements of Reform, The World Bank, Washington DC, p. xiv 
Dakolias states the importance of training programs for judges" ${ }^{\text {42 }}$ and the need to enhance the legal awareness of the public including "better education and access to the population at large". ${ }^{43}$ These pursuits of training programs and public awareness enhancement are expected to be conducted as tasks that supplement legal education.

The positive impact of legal education on the service quality of the justice sector does not lie in the number of graduates, but in the thresholds of competence, commitment to professional services and integrity upon graduation. This explains the caveat, underlined by Dakolias, against unrestricted access to public legal education because this can cause "excess supply of lawyers and therefore, a misallocation of resources" ${ }^{44}$ which could have been used for enhanced quality in legal education. The risk of unemployment after LL.B graduation, for example, is that law schools will eventually find it difficult to attract adequate percentage of candidates with a relatively high academic base during admission. This can have long-term adverse impact in legal education and the legal profession at large.

Ethiopia's legal education reform program is one of the components of the Justice System Reform Program. It had four pillars: ${ }^{45}$ (a) curriculum (b) delivery and assessment (c) law school management (which required autonomy of law schools in self-management including budget execution), and (d) research, publications and consultancy services. Community services (including legal aid in clinical programs and externship) were considered as part of the second pillar, i.e., delivery of legal education. The revised curriculum which was effective since September 2006, changed the years of legal education from four years to its previous duration of five years, introduced various skilled courses including externship and also introduced exit exam which is still in force.

One of the achievements of the legal education reform was the preparation of teaching materials which are made available to all Ethiopian law schools. Course Syllabi and teaching materials have been prepared for all LL.B courses. Teaching materials for 67 courses were "assessed at different workshops by assessors and different participants from law schools and other stakeholders" out of which 16 were "identified as below standard" ${ }^{46}$ There were plans to submit the latter to other course developers for upgrading. Moreover, some teaching materials that were rated as having excellent standards by the Curriculum

\footnotetext{
42 Ibid.

${ }^{43}$ Ibid.

${ }^{44}$ Ibid.

45 Justice and Legal System Research Institute, Ethiopian Legal Education Reform Program, 2006.

${ }^{46}$ Memo, Tasks on Curriculum Implementation, presented to Technical Committee for Ethiopian Law Schools, (Justice and Legal System Research Institute, January 03, 2011).
} 
Committee based on their content and form were expected to be upgraded and be published as books.

The category of targets under GTP I titled 'Human Resource Capacity development ${ }^{47}$ had envisaged the eight targets out of which the following seven targets expressly made reference to legal education, training and research:

- The full implementation of the new LL.B curriculum;

- The preparation, evaluation and regular updating of teaching materials for the LL.B curriculum;

- Pre-service training for newly appointed prosecutors and judges;

- Short-term training "at least once a year for judges and prosecutors serving at all levels ranging from Woreda to Federal Supreme Courts";

- Enhance the capacity of other professionals;

- Equip training institutes at federal and regional levels;

- Encourage 'research works that help build the capacity of professionals working in the justice sector'.

However the performance in this regard is not evaluated in GTP II. Nor does GTP II include a target toward the pursuance of the legal education reform which is underway since 2005/2006. The full implementation of the new LL.B curriculum that was expected during GTP I had envisaged the accomplishment of various projects based on the Guidelines that were developed through substantial inputs in expertise, budget and time. These Guidelines were meant to ensure the quality and standards of legal education with a view to preparing law graduates to the justice system commensurate with the level of competence, integrity, sense of citizenship and professional responsibility necessary for the sector. These instruments include:

- Regulatory Framework on Legal Education in Ethiopia;

- Regulatory Framework for Distance Legal Education in Ethiopia;

- Regulatory Framework for Short-Term Training in Ethiopia;

- Regulatory Framework on Continuous Legal Professional Development;

- Guidelines on Delivery and assessment;

- Guidelines on Research, publication, Consultancy and Community Service.

- Guideline for Teaching Material and Textbook Preparation

- Manual for Externship and Code of Conduct Governing Students engaged in Externship and Clinical Legal Education

- Manual on Exit Exam, and

- Other guidelines and manuals.

${ }^{47}$ Ministry of Finance and Economic Development (2010), Federal Democratic Republic of Ethiopia, Growth and Transformation Plan, 2010/11- 2014/15, Volume I, Main Text GTP I. November 2010, Addis Ababa, English Version, p. 102. 
With regard to graduate studies, the joint LL.M and $\mathrm{PhD}$ programmes with University of Alabama and University of Warwick were meant to lead to sustainable capacity building in the host law schools of Addis Ababa University and Mekelle University. Clusters were also formed so that more graduate programmes could be conducted (through twinning) to enhance the capacity of all clustered law schools. Even though the reform project has enhanced the tradition and outputs of research and publications, the pace at which it is progressing is slower than what was anticipated.

The third component of the legal education reform, i..e, the autonomy of law schools has not been implemented in most law schools. The level of autonomy in the various law schools is largely determined by the discretion of the university senates and presidents rather than the standards that were envisaged in the legal education reform program. Law schools are usually among the first faculties that are opened whenever a new university is established. It may seem easy to purchase some codes of law from Berhanena Selam Printing Press, print out the teaching materials prepared under the auspices of Justice and Legal System Research Institute (JLSRI), duplicate some books from a law school library, employ about four or five LL.B graduates and then admit law students in a newly opened university. However, the ultimate adverse impact of this rush (toward numbers, statistics and enrolment/graduate reports) is apparent. Even if the legacy of legal education was too elitist for a long time since the 1960s, the recent trends of abrupt overexpansion is bound to bring about graver harm to the legal profession and the justice system at large.

The challenge encountered by most law schools is the focus accorded to faculties and colleges based on the number of their students rather than the significance of the respective faculties, departments or colleges (irrespective of their enrolment size). Moreover, the focus on statistical figures of graduates (caused by a university's targets) has brought about pressure on law schools from university administrations which promote the motto of 'student

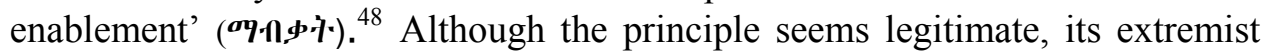
interpretation of enabling nearly all students (who are enrolled) to graduate adversely affects the efforts of students in the learning process thereby harming quality and standards of legal education. This exerts pressure on instructors to give tutorial assistance and make-up exams to students below ' $\mathrm{C}$ ' grades. It can also be a push factor for instructors to provide ' $C$ ' grades as the minimum threshold (for students who would have scored ' $\mathrm{D}$ ' or ' $\mathrm{F}$ ') in order to avoid the inconvenience of tutorials and make up exams. ${ }^{49}$

\footnotetext{
${ }^{48}$ Interview with a law school instructor who seeks anonymity; 18 December 2015.

${ }^{49}$ Ibid.
} 
During the initial years of legal education reform, JLSRI was the hub for the reform process by facilitating the coordination of Ethiopian Law Schools to own and manage the reform pursuits. JLSRI was in the midst of coordinating various legal education reform projects when it was required to leave its premises which were located in the compound of the Ministry of Finance and Economic Development at Sidist Kilo. The location was very convenient in view of its proximity to the Federal Supreme Court, Addis Ababa University, Ministry of Education and other stakeholders. It was also convenient for all law school representatives to use JLSRI offices and JLSRI Library during their stay in Addis. The projects of legal education reform were transferred first to Ministry of Justice and then to Higher Education Strategic Centre (HESC) at the Ministry of Education, thereby losing momentum and pace. At present, most of the elements of the legal education reform program are shelved except the Exit Exam which is still underway.

There is the need for enquiry regarding the reasons behind the relegation of legal education reform to the back seat. While change of hands between the JLSRI, Ministry of Justice and Ministry of Education in the coordination of the reform are the core factors for the decline in the pace and scope of the reform, the core motive that brought about steadily declining political commitment in legal education reform deserves a thorough research which is beyond the scope of this article.

GTP II does not make reference to legal education and research except the incidental mention that was made (in the earlier April 2015 version) which had expressed its aspirations toward the substitution of neo-liberal curriculum by developmental democratic curriculum; and applying the same in the fields of

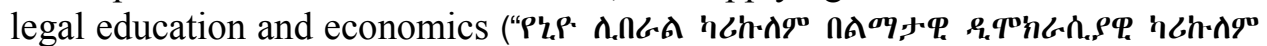

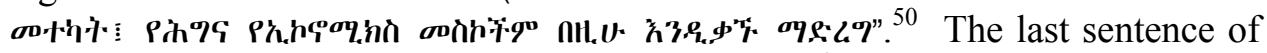
Item 3.16 of the earlier April 2015 Draft of GTP II ${ }^{51}$ had reiterated the need for such curriculum revision. This statement is duly omitted from GTP II. Yet, the issue deserves some discussion.

It is to be noted that neo-liberalism is a policy of extreme market deregulation, and it is already in the back seat in many countries after its 'years of blossom' known as the 'Washington-Consensus' of the late 1980s and early 1990s. Law curriculum which is based on ideology and indoctrination cannot be effective in preparing law graduates with analytic skills, diversified

\footnotetext{
${ }^{50}$ Ethiopian Federal Democratic Republic, Second Five Year (2015/15- 2019/20) Growth and Transformation Plan, Final Draft, (Amharic version) April 2015 (Miazia 2007 EC),

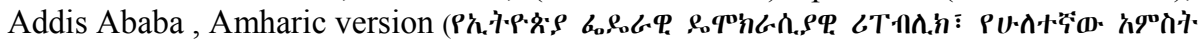

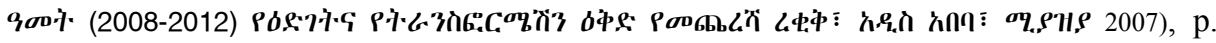
177.

${ }^{51}$ Ibid.
} 
perspectives, competence, integrity and responsibility. This is because any ideological patronage in legal education corrodes the key competence of being analytic and critical; it rather prepares graduates who are mostly 'fence-sitter" 52 paralegal clerks rather than lawyers.

As Frere ${ }^{53}$ notes, effective education is different from the 'banking model' in education which is analogous to depositing data in the minds of students and making inventories during exams. Effective legal education empowers and nurtures students with the cognitive, affective and behavioural competence and integrity in analysis, synthesis, problem solving and evaluation. It is in light of the need for such minds and souls that legal education reform should steadily continue during GTP II.

This should not, however, be misinterpreted as 'legal education for its sake'. Law curricula are expected to give due attention not only to 'black letter law' but also to the 'law in action' or the 'law in context'. Ethiopia's 2002 Policy Document titled 'Capacity Building Strategy and Programs' 54 notes the significant role of lawyers in economic development and states that legal education should not only focus on the letters of law but should also consider the law in the context of principles and objectives of economic development. ${ }^{55}$ What development pursuits require from legal education curricula is thus due attention to the law in action, by including relevant courses that give wider context to the contents of the curriculum. In other words, what is required of legal education is the preparation of students toward the graduate profile expressed in the curriculum which goes beyond 'black letter law'.

To this end, the revised LL.B curriculum has new courses, and one may argue that the gaps mainly relate to resources, effective delivery, periodic updating of the curriculum, and law school autonomy. As realities are dynamic, the curriculum (whose components including law school autonomy have not yet been fully implemented) requires further updating commensurate with unfolding global realities and advances in information technology. Apparently, the human resource base of the all justice sector institutions (and the legal profession at large) is legal education. Thus, the reinvigoration of the 2006 Legal Education

\footnotetext{
52 'Fence-sitters' are persons with workplace attitudes of just doing what the superiors assign based on the instructions and work rules.

53 Paulo Frere, Pedagogy of the Oppressed, 1970 (Translation into English by Myra Ramos), New York: Continuum, 2007.

${ }^{54}$ Government of Federal Democratic Republic of Ethiopia, Capacity Building Strategies

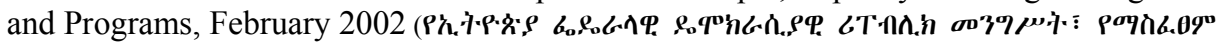

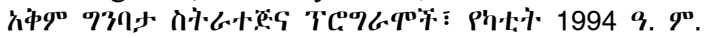

${ }^{55}$ Id. p. 292. The Amharic text reads: “...

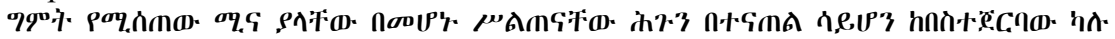

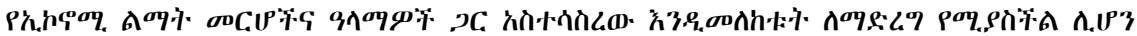
อากล:"”
} 
Reform Program including the autonomy of law schools in admissions, course delivery and assessment, resource allocation and management, and other avenues of empowerment and de-politicization (of assignments to offices, the learning and research environment, and employment opportunities after graduation) will determine the quality and features of Ethiopia's justice sector in the years and decades ahead.

\section{Access to Justice}

Access to justice involves various elements that are necessary for the effectiveness of claims and rights. For example "Ghana has an impressive record of encouraging public education on fundamental human rights as a means to improve citizens' access to justice" and this task involves NGOs "engaged in human rights promotion campaigns to complement education programmes conducted by two constitutionally mandated institutions". 56 There were challenges identified in the context of Ghana which included "geographical imbalance in the distribution of courts", corruption, shortages of judges at lower courts, rigid and formal court procedures, lack of legal aid, inadequate avenues of alternative dispute resolution and the "need to recognize important traditional court institutions". ${ }^{57}$

The experience of various countries shows that steadily increasing attention is being accorded to access to justice. Since the 1990s, most justice sector

${ }^{56}$ Ghana: Justice Sector and the Rule of Law. A Discussion Paper. (A review by AfriMAP and The Open Society Initiative for West Africa and The Institute for Democratic

Governance), An Open Society Network Publication, 2007, p. 17.

${ }^{57}$ Id., pp. 17, 18. The summary of the challenges states the following:

- geographical imbalance in court distribution tilted to favour areas with higher economic activities rather than areas with high density of population;

- corruption in the justice system and unreasonable delays [that] have resulted in erosion of the people's confidence in the courts;

- significant shortages of judges at [lower courts] ...;

- the cost of legal advice as an important impediment to accessing justice;

- a highly formalised court system, with strict rules of procedure for submitting a complaint;

- lack of adequate legal aid although the Constitution provides for legal aid for the indigent;

- the need for the promotion of alternative dispute resolution (ADR) to divert cases from the courts;

- the need to recognize important traditional court institutions which have important de facto jurisdiction, while ensuring that they are respectful of human rights, especially in relation to gender equality. 
reforms in Latin America include access to Justice. According to Maria Dakolias, the elements of judicial reform in Latin America have been:

- judicial independence through changes to judicial budgeting, judicial appointment, and disciplinary systems improving court administration through adoption of case management and court management reforms;

- adopting procedural reforms;

- providing alternative dispute resolution mechanisms;

- enhancing the public's access to justice;

- incorporating gender issues in the reform process; and

- redefining and/or expanding legal education and training programs for students, lawyers and judges. ${ }^{58}$

Dakolias further states the areas that need attention to enhance access to justice which include "the proper functioning of the [justice] system as a whole". ${ }^{59}$ She raises various factors in the evaluation of access to justice which include "the time it takes to adjudicate a case, the parties' direct and indirect costs of litigation (filing expenses, court and bailiffs' fees, attorneys' compensation, lost wages, etc.), the ability of the potential users to have knowledge of, understand and follow the procedural steps during the life of a case, and the physical access to the courts". ${ }^{60}$ The judicial system may thus "present economic, psychological, informational and physical barriers for individuals who need its services". ${ }^{61}$ The solutions toward overcoming or lessening certain economic barriers to justice include "reducing incidental costs to litigation, providing efficient legal aid programs and creating less expensive, alternative forms of justice ${ }^{62}$ which include Alternative Dispute Resolution Mechanisms. ${ }^{63}$

As Hammergren notes, ensuring the availability of the services whenever they are needed is important, "but it is a condition for, not the essence" of the services that are provided as public good. ${ }^{64}$ In the context of access to justice, "the public good derives from broad and equal access for all citizens to services intended to resolve their disputes and rectify alleged violations of their legally and constitutionally protected rights". ${ }^{65}$ Thus, 'the usual indicator of success' in

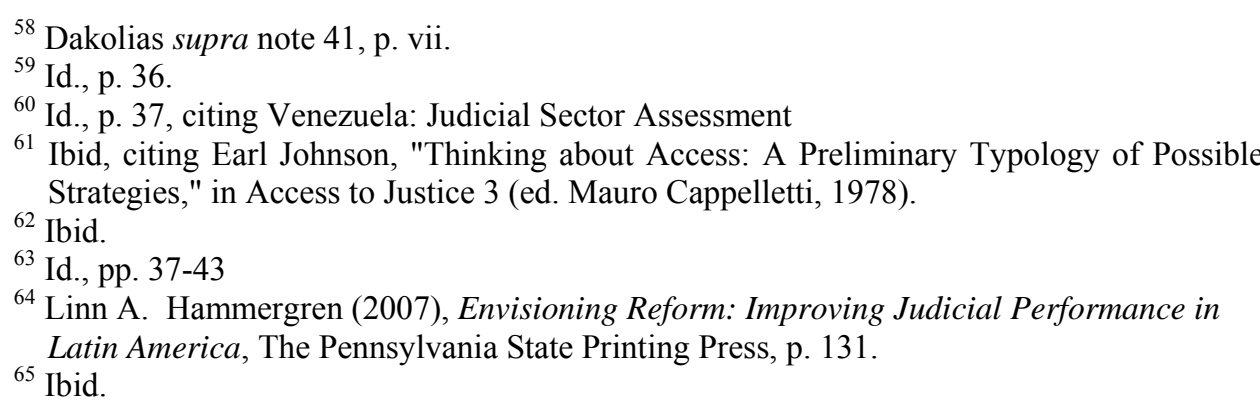


access to justice is the actual provision of the services and 'not abstract protection', and the indicators further include "more effective legal framework, or a reduced level of conflicts". 66

Hammergren states the difficulty in integrating the various elements of access to justice. Yet, she underlines that judicial reform and access to justice should be undertaken simultaneously. ${ }^{67}$ Justice system reform does not thus necessarily bring about access to justice unless it is part of the reform and if simultaneous efforts are not made to address the barriers of access to justice. This is also reflected in various development cooperation policies:

Legal development co-operation efforts have traditionally sought to promote 'the rule of law' through legal reform and institutional strengthening (mainly of the judiciary). While access to justice has sometimes been a part of these programmes, it was not their main goal. More recently, under the influence of the global struggle against poverty, legal reform programmes have shifted their focus to the justice seeker, in particular the poor and the marginalised, in particular women and indigenous people. This shift from top-down institutional reform to bottom-up intervention informs the new focus on access to justice and the new strategy of legal empowerment. ${ }^{68}$

Article 37 of the Constitution guarantees "the right to bring a justiciable matter to, and obtain decision or judgements by, a court of law or any other competent body with judicial power". ${ }^{69}$ Such right can be invoked by individuals, ${ }^{70}$ or by any association which represents "collective or individual interest of its members", ${ }^{71}$ or by "any group or person who is a member of, or represents a group with similar interests". ${ }^{72}$ The constitutive ingredients of

${ }^{66}$ Ibid.

${ }^{67}$ p. 166. She notes:

"Rather than treat this as a chicken-and-egg proposition, the dilemma would appear to argue for a simultaneous (and, one would hope, better coordinated) or iterative approach on both fronts. Strengthening the judiciary first, without attending to access, could reinforce isolation. Pushing access without other improvements may be costly, unnecessarily difficult, and unrewarding. The current tendency to parallel, but less coordinated programs is not quite the answer. Still, like all the partial approaches, it has been the easiest for the participants to adopt."

${ }^{68}$ Ineke van de Meene and Benjamin van Rooij (2008), Access to Justice and Legal Empowerment, Leiden University Press, p. 6.

${ }^{69}$ According to Article 79(1) of the FDRE Constitution, "Judicial powers, both at Federal and State levels, are vested in the courts." The words "any other competent body with judicial power' in Article 37 are given restrictive interpretation and they refer to forums such as arbitration, etc.

${ }^{70}$ FDRE Constitution, Art. 37(1).

${ }^{71}$ Id., Art. 37(2)(a)

${ }^{72}$ Id., Art. 37(2)(b) 
Article 37(1) include the right to institute a claim, and the right to obtain decision or judgement. These core elements presuppose:

a) awareness about the law and the accessibility of laws and other data which are relevant (i.e. legal information including registration and accessibility of various data);

b) professional advise or representation in preparing claims, counter-claims, defences, arguments in court, etc.

c) obtaining judgement in accordance with the law within reasonable time.

As Tamrat Kidanemariam (president of Ethiopian Lawyers Association) observes, the right of access to justice "envisages factors from three dimensions, namely the law, the bench and the parties to the suit or trial". ${ }^{73}$

The first factor requires laws, processes and practices which do not deny or restrict the right to bring justiciable matters to courts of law (or other relevant tribunals). The second factor relates to independent, competent and impartial courts in the context of integrity against corruption. And third, legal services should exist, and in particular, persons who do not afford to hire a lawyer should be provided with free legal service. ${ }^{74}$

Access to justice presupposes the existence of the normative dimension that relates to the content and form of laws, and the adjudicative dimension to which the claims are made and from which decisions and judgements are sought. These two settings enable access to justice only when adequate public awareness and (fairly comparable) legal services of advising and representation exist to both sides of the litigation. While the normative and the adjudicative preconditions for access to justice relate to lawmaking and the judiciary, the realization of access to justice require access to legal information and the availability of legal services.

These core elements of access to justice were not addressed in the earlier April 2015 Draft GTP II, other than the brief reference made to the 'publication and distribution of binding cassation decisions ${ }^{75}$ and reference to capacity building of "institutions that are in charge of registration of vital events" and enhancing their performance in the registration of vital events such as birth, marriage and death. ${ }^{76}$ This gap is (to some extent) rectified in GTP II because it incorporates targets that relate to legal information, the Bar and ADR.

\footnotetext{
${ }^{73}$ Foreword, in Abera Hailemariam (2015). "Public Defenders Services in Ethiopia: Assessment of Current Gaps and the Way Forward", EN Stebek, ed. (Ethiopian Lawyers Association, December 2015), p. 5.

${ }^{74}$ Ibid.

${ }^{75}$ April 2015 Draft GTP II, supra note 50, p. 173.

${ }^{76}$ Id., p. 174.
} 
Six issues deserve attention in relation with access to justice. They are legal information, the Bar, legal aid, alternative dispute resolution (ADR), recognition of traditional systems (that are in conformity with the FDRE Constitution), and the role of the legal profession and civil society organizations in access to justice and justice system oversight.

\subsection{Legal Information}

There are indeed achievements in the accessibility of legal information. They include online accessibility of proclamations, regulations and Federal Supreme Court cassation decisions. Yet, there is much to be done by the respective organs of the justice sector in availing legal information on websites that are functional and updated. One of the components of justice sector reform in the 2005 CJSRP refers to 'information flow within and outside the justice system'. The ambitious project on 'National Integrated Justice Information System for the Ethiopian Justice Institutions' (NIJIS) seems to take longer that what was anticipated.

World Bank and other donors were involved in the NIJIS project. A significant budget was allotted to it. And a very extensive field work was done. The project envisages three phases. Now that the first phase is done, focus should be given to the next phases". ${ }^{77}$

Legal information to the wider public and within institutions of the justice sector can have modest start ups and organically develop onto steady achievements toward long-term goals. For example, law blogs such as Ethiopian Legal Brief, ${ }^{78}$ Abyssinia Law ${ }^{79}$, etc. deserve appreciation. Another commendable initiative in the avenue of legal information is a project that is initiated by African Law Library ${ }^{80}$ to support the enhancement of access to legal information in Africa. One of the outcomes of this project is EtLex Volume $1^{81}$ in which English translations of one hundred Federal Supreme Court Cassation Division decisions were published along with thematic index to all proclamations and regulations enacted from 1995 to 2012. As Dr. Menberetsehai Tadesse (former Vice President of the Federal Supreme Court) noted, even if the project was "a small addition in the justice process, it will have a big impact" as a contribution in the domain of legal information. ${ }^{82}$ The lesson that can be drawn from the

\footnotetext{
${ }^{77}$ Interview with Belen Teferi, November 19, 2015, International Cooperation on Legal Affairs Directorate Public Prosecutor, Ministry of Justice.

${ }^{78}$ Available at $<\mathrm{http}: / /$ chilot.me/ $>$

${ }^{79}$ Available at $<\mathrm{http}: / /$ www.abyssinialaw.com/ $>$

${ }^{80}$ Available at $<\mathrm{http}: / / \mathrm{www}$.africanlawlibrary.net/>

${ }^{81}$ EtLex Vol. 1, Selected Federal Cassation Decisions, and Ethiopian Law Index (19952012), Justice and Legal System Research Institute, December 2013.

${ }^{82}$ Task Launching Event of African Law Library Project (organized by Justice and Legal System Research Institute In collaboration with two other members of the Ethiopian Legal Information Consortium), August 22, 2013. Dr. Menberetsehai Tadesse (former Vice
} 
good practices in Ghana (indicated above) is the need to enhance public awareness which is among the core factors that enhance legal information.

\subsection{The Bar and the Legal Profession}

Professional associations are standard bearers, gate keepers and watchdogs with regard to the level of professionalism and legitimate practice of any occupation. For example, the American Bar Association sets the standards in legal education (used in all law schools) and it is also in charge of Bar exams that are entry points to law practice. Members of a professional association benefit from various professional development schemes in competence and integrity. Such levels of professionalism are crucial in economic development because they facilitate predictability, efficiency, effectiveness and integrity in the justice system in general. This in return facilitates the quality, efficiency and effectiveness of the justice sector.

The Communiqué of the Joined-up Justice Forum (issued on 10 November 2015) notes the adverse impact of some corrupt advocates who broker court decisions thereby putting pressure of corruption on the judiciary. ${ }^{83}$ This concern was also stated in the Justice Sector's 2015-2016 Good Governance Movement Launching Document which (under Section 5.3) expresses its concerns regarding the standards of competence and integrity in the Bar. ${ }^{84}$ Enhancing the competence, integrity and responsibility of associations in the legal profession including the Bar and other civil society organizations (involved in activities relevant to the justice sector) positively contributes to the quality of performance in all components of the justice system.

As various participants of the panel discussion on Justice Sector Reform Components in GTP I and Draft GTP II noted, the Bar and the legal profession in general are among the key factors in justice sector reform. The following remarks were made during the Panel Discussion:

- "Lawyers associations should be given attention comparable with other components of the justice system" ${ }^{85}$ Practicing lawyers are "components of the justice system. There is the tendency of giving more emphasis to the controlling aspect and magnifying the weaknesses of persons who only

President of the Federal Supreme Court) was the Director General of JLSRI (2010- 2014), and he was chairperson of the Ethiopian Legal Information Consortium in 2013-2014.

${ }^{83}$ Joined-up Justice Forum, Communiqué, 10 November 2015, Hawassa, p. 2, Item 6. (hoc

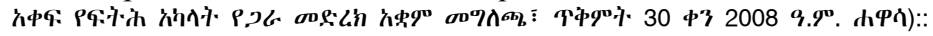

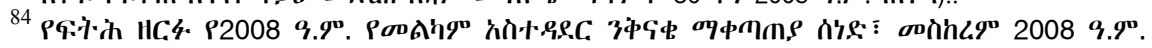
(Justice Sector's 2015-2016 Good Governance Movement Launching Document), September 2015, pp. 13-14.

${ }^{85}$ Ato Reshid Seid, Ethiopian Young Lawyers Association, Board Chairperson, Panel Discussion, supra note 21. 
represent few practicing lawyers. This cannot be generalized for the entire profession". ${ }^{86}$

- "The criticism is not against all lawyers. But there is the tendency from various persons with court cases to inquire whether an attorney knows the judge. Good governance in the justice sector envisages professional integrity and the competence of practicing lawyers" ${ }^{87}$

- "Participation is one of the principles pursued by the Ministry of Justice and practicing lawyers will be encouraged to participate in various pursuits of the Ministry of Justice. For example, Ethiopian Lawyers Association can be invited to participate in drafting, training and similar engagements". 88

- "Ethiopia's legal services should be at a level that is required by the pace of economic development, contract enforcement and investment. Legal Service Provision, as a component of justice sector reform, does not only include practicing lawyers, but it also encompasses lawyers that are employed in the public and private sector to advise and represent institutions. The relevant government organs should not only have positive attitudes toward practicing lawyers, but should also regard them as partners in the efforts toward justice sector reform. The capacity building pursuits during GTP II should also include practicing lawyers". 89

\subsection{Legal Aid}

Legal aid to the indigent is one of the areas that need due attention in the realm of access to justice. The right of an accused person to be provided with the legal service of representation at the state's expense -if he/she cannot afford to hire a lawyer- is ensured under Article 20(5) of the FDRE Constitution. However, studies show gaps in this regard owing to the legal framework and other constraints including budgetary, human power and institutional challenges that are encountered in public defender's services. ${ }^{90}$ The gaps in this regard are so wide that they can neither be covered by the pro bono services to be provided by

${ }^{86}$ Ato Tamrat Kidanemariam, President of Ethiopian Lawyers Association, Panel Discussion, Ibid.

${ }^{87}$ Ato Desalegn Mengistie, Director of Justice System Reform Program Office, Ministry of Justice, Panel Discussion, Ibid.

${ }^{88}$ Ato Fekadu Demissie, Director of Advocates Licensing and Administration Directorate, Ministry of Justice, Panel Discussion, Ibid.

${ }^{89}$ Ato Gebreamlak Gebregiorgis, Ethiopian Lawyers Association, Chairman of Legal Aid Committee, Panel Discussion, Ibid.

${ }^{90}$ See, for example, Abera Hailemariam, supra note 73; and Hussein Ahmed Tura (2013), "Indigent's Right to State Funded Legal Aid in Ethiopia". International Human Rights Law Review, 2. 
practicing lawyers in Ethiopia ${ }^{91}$ nor the clinical legal aid programmes that are underway in various law schools. Significant achievements in this regard require the establishment of an independent Public Defender's Office with due autonomy, budget and professional staff during the GTP period.

\subsection{Alternative Dispute Resolution}

GTP II envisages the drafting of laws on Alternative Dispute Resolution. ${ }^{92}$ The earlier April 2015 Draft GTP II had also included a target regarding the need to encourage 'the public to use Alternative Dispute Resolution (ADR) schemes such as reconciliation and arbitration'. ${ }^{93}$ As Ato Gebreamlak Gebregiorgis duly observes, Ethiopia's justice sector "should be able to provide legal services such as alternative dispute resolution forums and facilities at the level that is acceptable by international institutions of arbitration and investors" because "efficient economic activities and investments seek wide and effective opportunities for alternative dispute resolution". 94 He further notes that in the absence of such ADR forums "arbitration at international forums will be very costly for Ethiopia". 95

\subsection{Recognition of Traditional Systems}

Institutions of justice include not only formal institutions but also embrace traditional institutions that offer access to justice as long as the content of the traditional normative system and the process are not in violation of the Constitution. Enhanced legal pluralism is envisaged during GTP II. There are commendable achievements in the avenue of research and publications (on traditional legal systems) by Justice and Legal System Research Institute (JLSRI), and this is expected to sustained.

\subsection{Public Participation and the Role of Civil Society Organizations}

The various elements of access to justice evoke the issue of public participation and the role of civil society organizations. GTP II embodies a target regarding the need for establishing "public empowerment structures which encourage comprehensive public participation and enhance law-abiding and peaceful citizenry". 96 Public participation becomes meaningful if it goes beyond

${ }^{91}$ Pursuant to Article 49 of the Federal Court Advocates' Code of Conduct Regulations No. $57 / 1999$ practicing lawyers are required to provide pro bono services for at least fifty hours a year.

${ }^{92}$ GTP II (December 2015), supra note 18, p. 168.

${ }_{93}$ April 2015 Draft GTP II, supra note 50, p. 174.

${ }_{94}$ Gebreamlak Gebregiorgis, Panel discussion, supra note 21.

${ }_{95}^{95}$ Ibid.

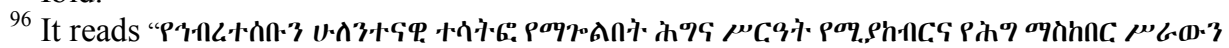

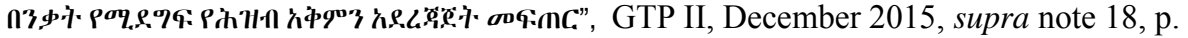
168. 
spontaneous engagements which lack continuity and institutional memory. For example, if the participants are different persons who merely speak out their views without formal records and in the absence of a steady transfer of information to persons who will be engaged in future public participation, the forums cannot be effective.

Section 7.2.1 of GTP II (titled Strengthening Public Participation) states that follow up and support will be made to societies and charities during GTP II period. $^{97}$ Even though the section that deals with the justice sector does not address the role of civil society organizations in relation with access to justice, the target mentioned in Section 7.2.1 of GTP II can have positive impact in this regard. Civil society organizations not only enhance legal information, the performance of the Bar, legal aid, ADR, the recognition of traditional systems, and public participation, but they also serve as instruments of oversight and feedback. This issue is briefly discussed in Section 7.

\section{Good Governance}

Kaufmann, Kraay and Mastruzzi define governance as "the traditions and institutions by which authority in a country is exercised". This, according to Kaufmann et al, includes "(a) the process by which governments are selected, monitored and replaced; (b) the capacity of the government to effectively formulate and implement sound policies; and (c) the respect of citizens and the state for the institutions that govern economic and social interactions among them". 98 In other words, the first general component relates to the legitimacy of holding power, deserved and merit-based assignments to office or position, control over and the accountability of office holders or persons with authority including the capacity to recall and replace them. The second general component of good governance refers to effective performance through sound policies, while the third general component focuses on the domain of outcomes and impact as, inter alia, manifested in the confidence of citizens and the state in general on the institutions that govern their economic, social and political interactions.

Kaufmann et al have formulated two measures of governance which correspond "to each of these three areas, resulting in a total of six dimensions of

${ }^{97}$ GTP II, supra note 18, pp. 170-171. The original Amharic version reads "P.nH.4 29 Pad. $\rho$

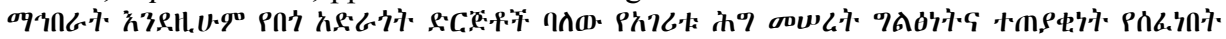

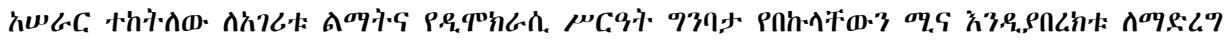

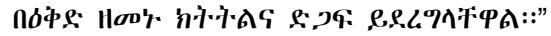

${ }^{98}$ Daniel Kaufmann, Aart Kraay and Massimo Mastruzzi (2010), The Worldwide Governance Indicators: Methodology and Analytical Issues, Global Economy and Development at Brookings, p. 1. 
governance" ${ }^{99}$ namely: voice and accountability, political stability and absence of violence, government effectiveness, regulatory quality, rule of law and control of corruption.

This model avoids the pitfalls of extremely wide and narrow definitions of governance, and it also provides holistic approach in which the dimensions are interrelated. As Kaufmann et al illustrate "accountability mechanisms lead to less corruption, or that a more effective government can provide a better regulatory environment, or that respect for the rule of law leads to fairer processes for selecting and replacing governments and less abuse of public office for private gain". 100

These six dimensions are currently in use as Worldwide Governance Indicators. ${ }^{101}$ The first dimension relates to the foundation of state legitimacy, and, in the context of the justice system, it requires merit-based assignments, appointment and accountability. The second dimension refers to peace and

${ }^{99}$ Id., p. 4.

They are:

(a) The process by which governments are selected, monitored, and replaced:

1. Voice and Accountability (VA): ... the extent to which a country's citizens are able to participate in selecting their government, as well as freedom of expression, freedom of association, and a free media.

2. Political Stability and Absence of Violence/Terrorism (PV): ... the likelihood that the government will be destabilized or overthrown by unconstitutional or violent means, including politically motivated violence and terrorism.

(b) The capacity of the government to effectively formulate and implement sound policies:

3. Government Effectiveness (GE): ... the quality of public services, the quality of the civil service and the degree of its independence from political pressures, the quality of policy formulation and implementation, and the credibility of the government's commitment to such policies.

4. Regulatory Quality (RQ): ... the ability of the government to formulate and implement sound policies and regulations that permit and promote private sector development.

(c) The respect of citizens and the state for the institutions that govern economic and social interactions among them:

5. Rule of Law (RL): ... the extent to which agents have confidence in and abide by the rules of society, and in particular the quality of contract enforcement, property rights, the police, and the courts, as well as the likelihood of crime and violence.

6. Control of Corruption (CC): ... the extent to which public power is exercised for private gain, including both petty and grand forms of corruption, as well as

${ }^{100}$ Id., p. 5. "capture" of the state by elites and private interests.

${ }^{101}$ The World Bank, Worldwide Governance Indicators $<$ http://info.worldbank.org/governance/wgi/index.aspx\#home> 
stability (in which the justice sector plays a crucial role and) which constitute $a$ sine qua non condition for social, economic and political interactions in society. As the justice sector is part of the public service, the third dimension, i.e., government effectiveness applies to the justice sector as well. The fourth and fifth dimensions specifically relate to the justice sector, because, the dimension of regulatory quality, inter alia, relates to the lawmaking component of the justice system, while the rule of law dimension is relevant to most components of the justice sector. The sixth dimension, i.e. the control of corruption, is relevant for the entire public service including the justice system.

Reform toward good governance thus requires a comprehensive approach to these dimensions in which the justice system plays an important role. Vanda argues that governance reforms can succeed only if "the state and governing institutions [are] reformed and strengthened; effective democratic institutions established; and effective participation, strengthened accountability, and enhanced rule of law instituted" with a view to ensuring "sustainable good governance". ${ }^{102}$

The Joined-up Justice Forum that was held in Hawassa on November 9 and 10,2015 has evaluated reform and good governance in the various organs of the justice system, and has also stated the directions to be pursued by the institutions in the sector. After having examined the internal and external environment in which the justice sector functions, ${ }^{103}$ the issues that were raised include performance and challenges regarding leadership, employees, public participation, private law practice, and legal education, training and research. ${ }^{104}$ Problems and potential solutions were identified with regard to the problems related with good governance in the police, public prosecutor services, courts, and prisons. The Forum has further formulated a system of follow up and support. ${ }^{105}$ The problems identified by the Forum regarding good governance are related to processes in operations ( $h \omega(\cdot C)$ ), institutional framework (h.S.C. T), human resource and laws. ${ }^{106}$ In general, it is believed that the sector has substantial gaps in performance and the Forum has underlined the need to address these gaps and challenges. ${ }^{107}$

${ }^{102}$ Ved P. Nanda (2006), “The 'Good Governance' Concept Revisited', The Annals of the American Academy of Political and Social Science, Vol. 603, Law, Society, and Democracy: Comparative Perspectives (Jan., 2006), p. 281.

${ }^{103}$ Report of the Joined-up Justice Forum, November 9 \& 10, 2015, Hawassa.

${ }^{104}$ Ibid.

${ }^{105}$ Ibid.

${ }^{106}$ Ibid.

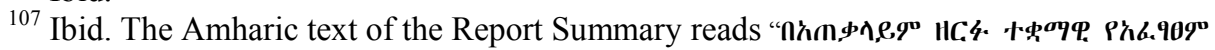

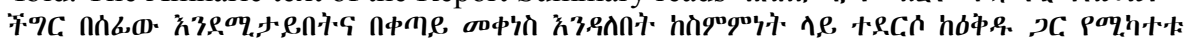

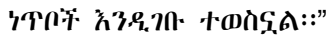


Various parts of GTP II address the issue of good governance. The themes apply to the justice sector as well because they make reference to the civil service in general. All components of the justice sector involve governance. And every gain in any of these components positively contributes to good governance which cannot be imposed 'top down' or be legislated as law. Good governance emerges and develops through the dynamics that nurture and enhance its elements. On the other hand, weak governance is, inter alia, related with gaps in governing institutions, and in return these institutions are weak because of their economic, social, cultural and political realities.

At the national level, the chicken-egg paradox related with governance cannot be resolved by purely legalistic means or through policy declarations. The vicious cycle in the causal link between weak governance and deepening impoverishment (even in the midst of non-inclusive 'statistical claims of growth') pushes a country toward poverty and fragility traps. And on the contrary, every success at the foundational ingredients of sustainable development including components of the justice sector will positively contribute toward transposing the negative vicious cycle onto a positive virtuous cycle whereby the dimensions of progress enhance the levels of democratization and rule of law.

\section{Projects under Justice Sector Reform Program - versus - Good Governance Reform Cluster Strategic Plan}

The Justice Sector Reform Program had fifty four projects for the GTP I period' which included thirty projects under the Sub-Program for Law Enforcement Reform and eight projects under the Sub-Program for Enhancing Legal Education, Training and Research. Three out of eight projects under the latter Sub-Program are not included in Good Governance Reform Cluster projects for the GTP II period. They are (a) the projects that deal with strengthening and reforming legal education, (b) establishing a system to evaluate the effectiveness and education and training institutions and (c) IT enhancement project for law schools, JLSRI and JOPTC.

The projects during GTP I under the Sub-Program for Law Enforcement

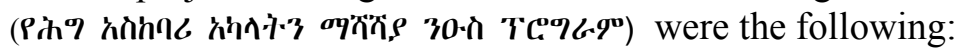




\begin{tabular}{|c|c|c|c|}
\hline 1 & $\begin{array}{l}\text { Human resource development } \\
\text { project }\end{array}$ & $\underline{16}$ & $\begin{array}{l}\text { Project for the enforcement and } \\
\text { enhancement of Alternative Dispute } \\
\text { Settlement schemes }\end{array}$ \\
\hline 2 & $\begin{array}{l}\text { Capacity building project for } \\
\text { administrative and security affairs } \\
\text { offices }\end{array}$ & 17 & $\begin{array}{l}\text { Legal aid services improvement } \\
\text { project }\end{array}$ \\
\hline 3 & $\begin{array}{l}\text { Capacity building project for the } \\
\text { police }\end{array}$ & 18 & $\begin{array}{l}\text { Project for the rehabilitation, } \\
\text { correction and administration of } \\
\text { prisoners }\end{array}$ \\
\hline$\underline{4}$ & $\begin{array}{l}\text { Project for community police } \\
\text { capacity building and assignments }\end{array}$ & 19 & $\begin{array}{l}\text { Federalism and inter-state relation } \\
\text { enhancement project }\end{array}$ \\
\hline 5 & $\begin{array}{l}\text { Project to enhance and consolidate } \\
\text { community-based crime prevention } \\
\text { system }\end{array}$ & $\underline{20}$ & Project to enhance values of peace \\
\hline 6 & $\begin{array}{l}\text { Project for the formulation and } \\
\text { enhancement of a system for } \\
\text { witnesses and crime victims }\end{array}$ & $\underline{21}$ & $\begin{array}{l}\text { Project to enhance systems for pre- } \\
\text { conflict interventions and post- } \\
\text { conflict responses }\end{array}$ \\
\hline 7 & $\begin{array}{l}\text { Criminal and civil justice reform } \\
\text { project }\end{array}$ & 22 & $\begin{array}{l}\text { Project to enhance public } \\
\text { participation in the justice system }\end{array}$ \\
\hline 8 & $\begin{array}{l}\text { Project for registration of vital } \\
\text { events }\end{array}$ & $\underline{23}$ & $\begin{array}{l}\text { Project to strengthen lawyers } \\
\text { associations }\end{array}$ \\
\hline 9 & $\begin{array}{l}\text { Forensic investigation and } \\
\text { laboratory establishment and } \\
\text { enhancement project }\end{array}$ & $\underline{24}$ & $\begin{array}{l}\text { Project for follow up and support } \\
\text { system of charities, civic societies } \\
\text { and private security guard entities }\end{array}$ \\
\hline$\underline{10}$ & $\begin{array}{l}\text { Project for firearms and armaments } \\
\text { administration and procedures }\end{array}$ & 25 & $\begin{array}{l}\text { Justice sector organs coordination } \\
\text { project }\end{array}$ \\
\hline$\underline{11}$ & Prosecution file system project & 26 & $\begin{array}{l}\text { Project to enhance the operations of } \\
\text { law enforcement organs by ICT }\end{array}$ \\
\hline 12 & $\begin{array}{l}\text { Project for legal drafting in } \\
\text { accordance with the Constitution, } \\
\text { and consolidation of laws }\end{array}$ & 27 & $\begin{array}{l}\text { National Integrated Justice } \\
\text { Information System (NIJIS) project }\end{array}$ \\
\hline 13 & $\begin{array}{l}\text { Project to establish a system for } \\
\text { public evaluation of justice organs }\end{array}$ & 28 & $\begin{array}{l}\text { Justice Organs Integrated } \\
\text { Information Center establishment } \\
\text { project }\end{array}$ \\
\hline 14 & $\begin{array}{l}\text { Project to enhance the awareness of } \\
\text { the public on law }\end{array}$ & 29 & Project to dispose of dead files \\
\hline 15 & $\begin{array}{l}\text { Project for premises and other } \\
\text { facilities }\end{array}$ & 30 & $\begin{array}{l}\text { Project to enhance and strengthen } \\
\text { performance in cross-cutting issues }\end{array}$ \\
\hline
\end{tabular}

Eight projects stated under serial numbers 4, 10. 11, 16, 20, 21, 23 and 24 here-above are not included in the list of Good Governance Reform Cluster Projects for the GTP II period. 


\section{The Role of Civil Society Organizations in Justice Sector Reform}

Civil society organizations in their modern conception emerged as entities outside the periphery of the state, and there is the propensity toward harmony and tension between them depending on the avenues of (a) cooperation and conflict, and (b) the level of democratization in a country. They are voluntarily established and registered non-governmental and non-profit entities that operate in accordance with the law. The Charities and Societies Proclamation ${ }^{108}$ states the need "to aid and facilitate the role of Charities and Societies in the overall development of Ethiopian Peoples". ${ }^{109}$ It classifies civil society organizations into various categories ${ }^{110}$ and regulates their establishment, registration, source of fund and operations. The Proclamation shall not apply to religious institutions, Edir, ${ }^{111}$ Equb $^{112}$ and societies governed by other laws. ${ }^{113}$

Civil society organizations do not compete for political office. Nor is the purpose of civil society organizations dissident or oppositional resistance to government. Yet, they have significant roles in tasks that positively contribute to economic development, social wellbeing and environmental sustainability. Civil society organizations involve themselves in hands-on activities which they consider is to the benefit of citizens. Their salient features include "the establishment of legal boundaries" that can ensure "an independent public space from the exercise of state power, and their ability to "influence the exercise of [state] power. ${ }^{114}$

There are historic events whereby political parties in power or office holders within a party brought about substantial reforms as in the case of perestroika and glasnost in the former Soviet Union. The same holds true for changes in China since the late 1970s. This shows that civil society organizations are not

${ }^{108}$ The Societies and Charities Proclamation No. 621/2009, Negarit Gazeta, $15^{\text {th }}$ Year, No. 25. $13^{\text {th }}$ February 2009.

${ }^{109}$ Id., Preamble, paragraph 2.

110 "Ethiopian Charities" or "Ethiopian Societies, "Ethiopian Residents' Charities", "Foreign Charities", and "Mass-Based Societies" which include "professional associations, women associations, youth associations and other similar Ethiopian societies."

${ }^{111}$ Edir is a traditional self-help association in Ethiopia established among neighbours for mutual support during difficulties such as funerals and to bear various responsibilities in organizing tents, etc during events such as wedding and mourning.

${ }^{112}$ Equb is a traditional saving scheme in Ethiopia in which members periodically deposit a certain amount of money (weekly, monthly, etc), so that the amount collected from members can be paid to each of them based on sequence determined by drawing lots.

${ }_{113}$ Proclamation No. 621/2009, supra note 108, Art. 3(2).

114 Michael Bernhard (1993), "Civil Society and Democratic Transition in East Central Europe”, Political Science Quarterly, Vol. 108, No. 2 (Summer 1993), p. 308. 
sine qua non reasons for reforms, although they can be contributory factors. Tolerance of a regime to civil society organizations does not also necessarily buttress their activities because the performance of civil society organizations in Botswana, for example, is not as strong as it could have been. On the other hand, Mexico is a good example for the substantial engagement of civil society organizations and their resultant impact in justice sector reform:

Mexico has historically featured a relatively weak civil society, due to the influence of corporatist structures controlled by the Mexican state. Yet, with regard to the criminal justice system..., Mexican civil society has recently shown some encouraging signs of engagement and activism in response to significant rule of law and security concerns. Specifically, with regard to judicial reform, Mexican civic activists were very engaged in the historic 2008 constitutional and legal reforms that produced one of the most important changes in Mexico's contemporary history. ${ }^{115}$

Civil society organizations can play significant roles "in complementing the activity of the state by filling [gaps]". ${ }^{116}$ The fifth component of the justice system reform program that was identified in 2002 was 'professional and civic legal associations". 117 Moreover, 'enhancing the "role of civic societies and stakeholders in good governance and development activities' was one of the implementation strategies under GTP I. Likewise, Section 7.2.1 of GTP II states the need for following up and supporting societies and charities. As the following paragraphs indicate, civil society organizations can play constructive roles in all components of legal sector reform.

\subsection{Lawmaking}

Civil society organizations can support effective lawmaking through awareness enhancement about the problems they witness in the course of their activities. This serves as vital input in the course of policy decisions and legislative reforms. It enables the legislature to have wider perspectives on issues, problems, options in the solution of the problems and good practices of other countries. A case in point is the role played by Ethiopian Women Lawyers

115 Octavio Rodríguez Ferreira (2013), "Civic Engagement and the Judicial Reform: The role of civil society in reforming criminal justice in Mexico", Working Paper Series on Civic Engagement and Public Security in Mexico (Woodrow Wilson International Center for Scholars; the University of San Diego) August 2013.

${ }^{116}$ Sisay Gebregziabher (2002), "The Role of Civil Society Organizations in Democratization Process in Ethiopia”, Paper Presented at the Fifth International Conference of the International Society for the Third-Sector Research (ISTR)

"Transforming Civil Society, Citizenship and Governance: The Third Sector in an Era of Global (Dis) Order", July 7-10, 2002, University of Cape Town, South Africa, p. 9.

${ }^{117}$ Ministry of Capacity Building, Justice Reform System in Ethiopia: Proceedings of the Workshop on Ethiopia's Justice System Reform, Africa Hall, 7-8 May 2002, p. 43. 
Association (EWLA) in its awareness creation efforts toward reforming Ethiopia's family law under the 1960 Civil Code and its role in the lawmaking process of the 2000 Revised Family Code. It also had an important contribution during the revision of the 2004 Criminal Code. Members of the then Ethiopian Bar Association, (currently Ethiopian Lawyers Association) also had significant contributions during the revision of various laws, and many active members and participants were involved in law revision committees. Engaging civil society organizations and professional associations is thus expected to continue throughout the GTP II period.

\subsection{Law Enforcement}

Civil society organizations enhance public awareness about rights and capacity building. These are crucial factors in development and good governance. The contribution of Prison Fellowship-Justice for All in prison reform and in the various aspects of justice sector reform in general is commendable. Its partnership in various projects involves not only prison administrations, but other justice sector institutions as well.

The contribution of $\mathrm{APAP}^{118}$ illustrates the role that can be played by civil society organizations in law enforcement. It had "the aim of promoting accountability and transparency in the operation of low level government administration and law enforcement organs". To this end, it had "organized zonal level (the lowest political administration unit next to woreda) human rights education and training workshop for judges, prosecutors, administrators and police officials in different parts of the country". ${ }^{119}$

APAP's contribution in enriching Ethiopian jurisprudence in the area of public interest litigation is exemplary. On March 16, 2006, APAP had filed a suit at the Federal First Instance Court (Ref No AP/3. APN/045/98) against the Environmental Protection Authority. It required the respondent to have due diligence in taking the necessary measures that can stop the environmental pollution of Akaki River. In this public interest litigation, APAP requested the court to order the Environmental Authority to "enact laws which are delegated to it, and to exercise its power to fulfill its duties" 120 and "avert the pollution on the rivers and to clean up the pollution of the rivers". ${ }^{121}$ It also requested that "a commission from governmental and non-governmental organizations" be established to "follow up the measures taken by the Environmental Authority

\footnotetext{
${ }^{118}$ Action Professionals Association for the People, established in 1993

${ }^{119}$ Sisay Gebregziabher, supra note 116, p. 10.

${ }^{120}$ Tsegai Berhane and Merhatbeb Teklemedhin (2009), Environmental Law Teaching Material (Prepared under the sponsorship of Justice and Legal System Research Institute), pp. 133-141.

${ }^{121}$ Ibid.
} 
and submit report on the date fixed by the court". ${ }^{122}$ This illustrates the positive role of civil society organizations in law enforcement oversight. Even if discussing the merits of the case is beyond the scope of this article, it is worth to note that, a decade after APAP's suit against EPA (for lack of diligence in protecting Akaki River), the pollution has grown worse.

\subsection{Legal Education and Research}

Ethiopian legal education reform had envisaged the transfer of the reform program to Association of Ethiopian Law Schools (AELS) ${ }^{123}$, which was one of the projects in legal education reform. It was envisaged to be an association comparable to law school associations in other countries. The goals were envisaged to be:

"- Facilitate networking of law schools and external links;

- Create conducive forum for exchanging best practices and research outputs; and

- Strengthen efforts towards quality legal education". ${ }^{124}$

The thresholds of 'quality of legal education' are articulated in 60 standards. The standards have a general part (Standards 1-4), Standards for Curriculum (517), Standards for Delivery and Assessment (18-28), Standards for Management, Leadership and Organization (29-48), and Standards for Research, Publications and Consultancy Services (49-58), Other programs (Standard 59), and Quality Assurance (Standard 60). ${ }^{125}$ The Consortium of Ethiopian Law Schools was established and registered as a prelude to the establishment of the Association of Ethiopian Law Schools. However, the regression in the pace and scope of legal education reform (briefly indicated in Section 3) has not yet enabled the Consortium to develop onto an association.

In the realm of positive contributions for legal education and research, there are achievements of Ethiopian Lawyers Association (ELA) in publishing series of issues of a law journal, Ethiopian Bar Review. Legal education and the profession at large will benefit if Ethiopian Lawyers Association resumes the publication of its journal. Another noteworthy achievement by a civil society

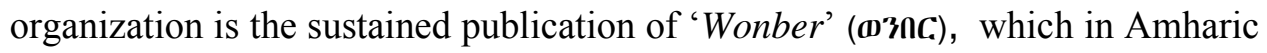
means 'The Bench'. It is a periodical published by Alemayehu Haile Foundation.

\footnotetext{
122 Ibid.

${ }^{123}$ Action Plan Item 28, Part VIII, The Ethiopian Legal Education and Training Reform Document, Justice and Legal System Research Institute (2006)

124 Association of Ethiopian Law Schools: Concept Paper Background: Objectives of AELS and Problems to be addressed, Justice and Legal System Research Institute, August 2009.

125 "Standards for Law Schools", Ethiopian Journal of Legal Education, Justice and Legal System Research Institute, Vol. 2, No. 1, January 2009, pp. 97-136.
} 
In the realm of textbooks, there was a significant achievement by a civil society organization, the American Bar Association Rule of Law Initiative (ABA ROLI) ${ }^{126}$ Legal Education Support Program in publishing law textbooks at enhanced level of content and standard through rigorous review processes which involved academics in and outside Ethiopia. As Mandefrot Belay, who was director of the program, recalls:

"the legal education support program was meant to enhance the overall capacity of the Ethiopian legal education system through reform projects focused on providing improved access to legal education resources via the development and publication of textbooks, building the skills of law students and enhancing the capacity of law school faculty as part of USAID`s program of support to the Ethiopian Justice Sector reform. The publication of textbooks and other research outputs by Ethiopian scholars and academics through funding by the program was a preferred option and this was thought to have positive impact in terms of building local capacity compared to earlier interventions such as book donations from abroad". ${ }^{127}$

Mandefrot further notes that "the program facilitated the review process and publication of six textbooks on the core subjects of the Ethiopian Legal Education Curriculum which was a rare success after nearly forty years of the publication of the first law textbooks by the Law School of Addis Ababa University". The books were distributed to Ethiopian Law Schools free of charge. "The next phase in the project was to proceed toward the publication of six other textbooks, and facilitate the $2^{\text {nd }}$ Edition of the textbooks published during the first round of textbook publications". ${ }^{128}$ Unfortunately, however, the project could not continue owing to the challenges it encountered in relation with registration.

\subsection{Access to Justice}

One of the components of the justice sector which benefits from enhanced involvement of civil society organizations is access to justice. EWLA, for example, represents indigent women. It has continued its active engagement in legal aid in addition to which it undertakes awareness creation including radio

${ }^{126}$ ABA ROLI did not continue with its project initiatives because its formal registration request as a foreign non-profit organization was rejected by Charities and Societies Agency. If registered, the office was meant to serve as a regional center for similar support in Africa in legal education and research as well, in view of Addis Ababa's location as seat of AU Headquarters.

${ }^{127}$ Interview with Ato Mandefrot Belay, former Director of the National Justice System Reform Program at the former Ministry of Capacity Building of the Government of Ethiopia on November 25, 2015.

128 Ibid. 
and TV programmes. ${ }^{129}$ EWLA has conducted survey on domestic violence, ${ }^{130}$ and this enables it to undertake its activities in the realm of access to justice based on research findings. ${ }^{131}$

As stated earlier, the right to legal aid to the indigent at the state's expense is enshrined under Article 20(5) of the FDRE Constitution. However, the facts at the grassroots show gaps between what the law envisages and the actual level and quality of legal aid which is available. This is an area of intervention that needs enhanced engagement of civil society organizations.

Another area of intervention that benefits from civil society organizations is alternative dispute resolution. For example, Addis Ababa Chamber of Commerce is facilitating ADR. Yet, there is the need for robust ADR forums in Ethiopia in view of the case load of courts, the delay that can result from court proceedings and the interest of parties to solve their disputes out of court. The Ethiopian Arbitration and Conciliation Center was a civil society organization which had commendable achievements in mediation and arbitration. The Center "used to work in five regions and the number of disputes settled out of court by mediation from September 2012 to October 2013 involved 29,142 (twenty nine thousand one hindered and forty two) cases". ${ }^{132}$ Haregewein Ashenafi, who was Executive Director of the Center, stated that "mediation was conducted (1) in kebeles, i.e. cases that come to Social courts; (2) in relation to cases that are handled by Community Policing and (3) at first Instance courts". ${ }^{133}$ The publication of four volumes of arbitration awards by the Center was another major contribution to Ethiopia's jurisprudence on arbitration, in addition to the importance of the volumes in legal education and research. ${ }^{134}$

${ }^{129}$ Interview with W/ro Zenaye Tadesse, Executive Director, Ethiopian Women Lawyers Association, 22 December 2015.

${ }^{130}$ Ibid

${ }^{131}$ Ibid.

${ }^{132}$ Interview with W/ro Haregewein Ashenafi, Former Executive Director of Ethiopian Arbitration and Conciliation Center, Nov. 30, 2015.

133 Ibid

134 Report of Arbitral Awards, Published by the Ethiopian Arbitration and Conciliation Center, Volumes 1 to 4 . The volumes embody selected arbitral awards rendered over a period of over three decades. The volumes were the following:

- Ethiopian Arbitration and Conciliation Center (2008), Report of Arbitral Awards, Volume 1, August 2008.

- Ethiopian Arbitration and Conciliation Center (2010), Report of Arbitral Awards, Volume 2, June 2010.

- Ethiopian Arbitration and Conciliation Center (2011), Report of Arbitral Awards, Volume 3, November 2011.

- Ethiopian Arbitration and Conciliation Center (2012), Report of Arbitral Awards, Volume 4, November 2012. 


\subsection{Good Governance:}

As Weiss observes:

"good governance is more than multiparty elections, a judiciary and a parliament, which have been emphasized as ... Western-style democracy. The list of other attributes, with the necessary resources and culture to accompany them, is formidable: universal protection of human rights; nondiscriminatory laws; efficient, impartial and rapid judicial processes; transparent public agencies; accountability for decisions by public officials; devolution of resources and decision making to local levels from the capital; and meaningful participation by citizens in debating public policies and choices. $^{135}$

Good governance -as briefly discussed in Section 5- is a process and not a single-step accomplishment. Nor can it emerge from promises and pledges. The elements of good governance thus involve standards of behaviour in all institutions of the legal sector with due caveat against exaggerating performance and downplaying weaknesses. This presupposes not only pursuits of the institutions in charge, but also requires stakeholder engagement and public participation including civil society oversight.

\section{Concluding Remarks}

Ethiopia's justice reform program has gone through various phases and institutional arrangements of coordination. The lessons drawn are the need to avoid being too ambitious (accompanied by over-centralization) and due caution against the other extreme of fragmented pursuits that lack grassroots empowerment and harmonization. The targets of the Justice Sector in GTP I for the period 2010-2015 had narrowed down the ambitious pursuits envisaged in the 2005 Comprehensive Justice System Reform Program (CJSRP). The 2005 CJSRP Baseline Study had recommendations, implementation strategies and action plans with specific objectives and actionable items that cover the components of the Judicial and legal sector reform. However, "the performance and challenges in the CJSRP have not been periodically evaluated by independent teams of experts based on well-developed evaluation tools and techniques". ${ }^{136}$

The CJSRP is a long term reform program intended to support development at all levels of the Ethiopian society. Its success can only measured by the

135 Thomas G. Weiss (2000). "Governance, Good Governance and Global Governance: Conceptual and Actual Challenges", Third World Quarterly, Vol. 21, No. 5 (Oct., 2000), p. 801

${ }^{136}$ Comment from one of the external reviewers. 
impact it brought about on the lives of the people and not just by the materials or inputs that go to it or by the number of people trained or the number of laws enacted. It requires commitment at all levels of leadership. In spite of the reform pursuits for over a decade, there are still major concerns which must be addressed. In some cases there is even an indication of backslide, and these are among the issues which must be investigated in future research. ${ }^{137}$

Even though the scope accorded to justice sector reform in GTP I was not as extensive as the initial years of the reform, the attention given to the sector was not peripheral. However, the scope of coverage given to the justice sector is further reduced in GTP II. Had this been caused by the level of attainment of the targets that were envisaged in the 2005 CJSRP and GTP I, the steady decline in the number of targets which specifically refer to the justice sector would have been acceptable. However, most of the concerns that prevailed during the takeoff point of the Justice System Reform Program are still relevant.

The assumption of responsibilities of reform by the respective organs during GTP I was indeed commendable. However, it could have been more effective in the context of enhanced institution-level empowerment in decision making and project implementation subject to sector-level harmonization. The earlier phases of the reform (2005-2010) were coherent and harmonized, inter alia, through a Steering Committee chaired by the Minister of Capacity Building. At present, there is Joined-up Justice Forum which meets twice a year in which various institutions of the justice sector participate. Each sector is in charge of its reform activities with some oversight. However there is the need for clarity as to which authority is at the wheels regarding the task of overall harmonizing. Such meaningful harmonization goes beyond organizing forums and reports. The gaps are thus two-fold owing to inadequate institution-level empowerment and the need for effective and efficient harmonization beyond the Joined-up Justice Forum.

Harmonization calls for effective coordination which can bring about higher impact in the performance of the entire justice system. Consistent alignment between the various elements is thus necessary so that each element facilitates the whole justice system and meanwhile avoids duplicity and fragmentation of efforts. This requires clear mandates and coherent management. However, the current institutional organs that are in charge of the various components of the reform are so fragmented that effective harmonization is inadequate.

The harmonization and strategic guidance of the reform at the level of the justice system in general does not have the requisite empowerment beyond a few modest tasks of coordination. This is contrary to the level of coordination

${ }^{137}$ Ibid. 
that existed during the initial phases of the reform. Such harmonization in the context of grassroots empowerment calls for reform management beyond periodic coordination and experience sharing that is facilitated by the Joined-up Justice Forum. Even though "the meeting of justice sector actors in the Joined up Justice Forum (twice a year) can be used as an important instrument in the dialogue between justice sector institutions and donors," the Forum "cannot substitute a well structured national justice system reform program management and coordination arrangement". ${ }^{138}$

It is at this juncture that the legal and judicial system reform pursuits are clustered into the Good Governance Reform cluster. It is impossible to incorporate all projects of the justice sector in the Good Governance Reform Cluster because the cluster includes various institutions outside the justice sector as well. Moreover, the exhaustive inclusion of justice sector targets and projects will rather alter the cluster onto the justice sector thereby adversely affecting the fair representation of other institutions in targets and projects. This challenge is already visible in the proportion of justice sector projects among the cluster's forty projects for the GTP II period. Thus, clustering strategic plans, targets and projects in a single document inevitably encounters challenges. Instead, clustering could have focused on harmonizing strategic plans at the macro level, and empowering the respective sectors and institutions in the formulation and implementation of their plans and projects.

The initial phases of the justice system reform had some challenges and gaps which do not, however, undermine the achievements and the level of vision, enthusiasm and commitment at all levels. Program reviews and evaluations could have been made in relation to each reform component. While regular monitoring and reviews could have been conducted to evaluate periodic performance, special reviews could have been made with regard to particular challenges and opportunities in program implementation. As one of the reviewers of this article noted "the main purpose of the review and evaluation should be improved management, more accountability and learning from experience". ${ }^{139}$ This envisages looking into the intended or unintended outcomes of the reform program at early stage, so that the reviews can facilitate the assessment of the reform "in relation to the higher level national objectives, i.e., impact, relevance and sustainability". ${ }^{140}$

In contrast to the earlier features of high thresholds of targets, the pace of justice system reform pursuits in GTP I (i.e. 2009/10 - 2014/15) reflects overreaction against centralized reform program rather than a synthesis that avoids

\footnotetext{
${ }^{138}$ Ibid.

${ }^{139}$ Ibid.

${ }^{140}$ Ibid.
} 
the pitfalls of the two extremes. The current measures of clustering in GTP II (2015/16 -2019/20) can aggravate the problems if the Good Governance Reform Cluster, substitutes the Justice System Reform Program targets and projects. Such clusters are merely expected to facilitate the harmonization of relatively independent (but not fragmented) reform programs which should be accorded autonomy in planning, decision making and budget administration.

Good practices in developmental states show the need for merit-based job placements and promotions at every unit and in all components of the justice sector. This further envisages resources (financial, physical, technological, and informational), processes, organization and leadership. Ethiopia's legal sector should thus deal with the roots of weak governance in the context of commitment to address the gaps and challenges thereof. This renders grassroots empowerment -in decision making and resource management- expedient. Such empowerment meanwhile presupposes harmonization among organs and institutions of the legal sector, and broad-based participation including enhanced involvement of civil society organizations in various pursuits of legal sector reform.

The balance in this regard should thus avoid the extremes of mechanical fragmentation and over-centralization. This needs a holistic justice system reform which facilitates synergy, harmony and experience sharing, while at the same time ensuring relatively autonomous legal sector reforms with the bigger justice system framework in view. In other words, each component deserves a reform programme and implementation plans of its own with due autonomy in needs assessment, planning, organizational arrangements, manpower, resource allocation, implementation, monitoring and evaluation subject to the need for horizontal and vertical synergy and harmonization within the justice system. This is because every positive change in each component enhances the level of efficiency, quality and public confidence in the justice system. To reiterate a point noted in Section 5, such changes and achievements can indeed positively contribute towards transposing vicious traps onto a positive virtuous cycle of progress, democratization and rule of law. 